\title{
$\AA$ Aj gjere «det som er liksom planen, da» - en kvalitativ intervjustudie av skolestress blant unge jenter som et strukturelt problem
}

\author{
Janne Lund, ${ }^{\star 1}$ Ole Jacob Madsen ${ }^{2}$ og Siri H. Haugland ${ }^{1}$ \\ ${ }^{1}$ Universitetet $i$ Agder, Norge og ${ }^{2}$ Universitetet $i$ Oslo, Norge
}

\section{SAMMENDRAG}

Stress blant jenter ser ut til å være knyttet til press om å gjøre det bra på skolen og er videre relatert til psykiske plager. I denne artikkelen undersøker vi hvordan skolestress arter seg i unge jenters hverdagsliv, og hvilke institusjonelle prosesser jentenes erfaringer inngår i. Vi tar utgangspunkt i 22 intervjuer med 10 jenter på 10. trinn fra skoler i Norge og beskriver vurderingsarbeid - deres tankearbeid og gjøremål som er knyttet til testing, vurdering og individuell forbedring. Vi drøfter skolestresset og vurderingsarbeidet elevene gjør opp mot prinsippene om tydelig vurderingskultur og forbedring i skolen slik som det kommer fram gjennom den pedagogiske satsingen Vurdering for lering. Vi finner at styringsrasjonalitet i skolen kan bære i seg en invitasjon til arbeidsprosesser som kan få uheldige utfall for noen elever. Avslutningsvis trekker vi fram at skolestress ikke kun må forstås som et individuelt symptom, men også som et logisk tilsvar til styringsrasjonalitet i skolen. Dersom man vil forebygge skolestress, kan endringer i skolehverdagens innhold og krav være vel så hensiktsmessige som individuelle mestringstiltak.

Nøkkelord: forbedring; institusjonell etnografi; psykisk helse; ungdom; vurdering

Mottatt: Januar, 2021; Godkjent: Mai, 2021; Publisert: Juli, 2021

\begin{abstract}
Doing "what's kind of the plan" - a qualitative interview study of school stress among adolescent girls as a structural problem

Performance stressors at school appear to be a main source of stress among adolescent girls; for some, such stressors are related to poor mental health. In our study, we investigate girls' experiences with school stress and the institutional processes to which this stress is related. Based on 22 in-depth interviews with ten girls in tenth grade from schools in Norway, we describe the girls' assessment work, which refers to their thoughts, reflections and actions related to testing, assessment and individual improvement. We relate school stress and assessment work to principles of
\end{abstract}

\footnotetext{
^Korrespondanse: Janne Lund, e-post: janne.lund@uia.no 


\section{F. Lund, O. F. Madsen \& S. H. Haugland}

assessment and improvement in school as they appear in the educational program Assessment for Learning. We find that for certain pupils, instrumental rationality in education may result in negative work processes. We conclude that school stress should be viewed as not only an individual symptom among girls, but also a logic that responds to instrumental rationality at school. If one intends to counteract negative stress among adolescent girls, it might be as important to focus on the content of schooling as on individual coping strategies.

Keywords: adolescents; assessment; improvement; institutional ethnography; mental health

\section{Innledning}

Skolestress har vært et gjennomgangstema i Norge i studier av ungdoms trivsel (Eriksen et al., 2017; Lillejord et al., 2017). Det er vist en sammenheng mellom $ø$ kte selvrapporterte psykiske helseplager og stress forbundet med skoleprestasjoner (Anniko et al., 2019; Eriksen et al., 2017; Moksnes et al., 2016; Skaalvik \& Federici, 2015; West \& Sweeting, 2003). Jenter rapporterer gjennomgående om langt flere symptomer på skolestress enn gutter (Högberg et al., 2020). Dermed synes skolestress å være et viktig område å utforske særlig blant jenter. Flere har også spurt seg hva det er med skolen som stresser ungdommene, og hvordan dette kan henge sammen med forhold i og utenfor skolen (Lillejord et al., 2017). En stor endring i den norske skolen fra og med 2010 er innføringen av underveisvurdering gjennom den fireårige nasjonale satsingen Vurdering for laering (VFL) (Utdanningsdirektoratet, 2019). Noen skoler har oppfattet VFL som skjematisk (Hopfenbeck et al., 2015), og selv om systematisk underveisvurdering ser ut til å gi økt læring, er det er påpekt en fallgruve ved at vurderingen kan etterleves for slavisk (Nortvedt et al., 2016).

I denne studien undersøker vi unge jenters erfaringer med skolestress og drøfter hvordan erfaringene oppstår i samspill med skolesystemet og utdanningsrelaterte føringer. Basert på intervjuer med jenter i tiende klasse spør vi: (1) Hvordan arter faglig skolestress seg $i$ unge jenters hverdag? (2) Hvordan er det relatert til foringer $i$ utdanningsinstitusjonen?

\section{En sosialt organisert hverdag}

Vår tilnærming tar utgangspunkt i Dorothy Smiths (2005) institusjonelle etnografi (IE), der man søker å forstå hvordan folks gjøremål hele tiden er sosialt organisert selv om det kan se ut som om problemene oppstår individuelt (Campbell \& Gregor, 2004; Smith, 2005). Folks levde liv og diskursene som finnes i et samfunn inngår i en felles dialog (Smith, 1996). Kunnskapen om noe, for eksempel skolestress blant jenter, finnes da hverken i individet selv eller i diskursene som omgir individet, men i møtet mellom disse. Fokusområdet til IE er nettopp dette møtet og det koordinerte i folks handlinger (Smith, 2002). Dette møtet kan kalles en styringsrelasjon og framtrer ved at folks aktiviteter viser seg å være knyttet til en felles styring. En slik styringsrelasjon kommer ofte til syne gjennom tekster som formidler forventninger (Smith, 2005). Tekstene kan ha en høyere eller lavere ordens rang, hvor eksempelvis 
lovtekster og læreplanen er høyere ordens tekster (Smith, 2006). Disse setter så rammer for hvordan man utformer tekster av lavere orden (Nilsen, 2015). Disse tekstene av lavere orden er konkret til stede i en skolehverdag, eksempelvis en ukeplan. En styring fra et dokument er imidlertid ikke noe som påføres folk i en passiv tilstand, det er $\left\langle\right.$ folk - alltid og utelukkende folk» ${ }^{1}$ som giennom sine handlinger gir praktisk innhold til styringen (DeVault, 2020, s. 84; vår oversettelse). Derfor er hva folk gjør, arbeidet deres, det sentrale anliggendet. Arbeid er hva folk bruker tiden sin på, hvilke faktiske giøremål og hvilket tankearbeid de legger ned innsats i, samt deres refleksjoner om dette (Smith, 2005). Noen ganger inngår arbeidet i et institusjonelt kretsløp der hverdagen består av en rekke handlinger, tankemåter og valg som formes av den institusjonelle organiseringen og av det som etterspørres gjennom tekster (Griffith \& Smith, 2014).

\section{Et kritisk blikk på utdanningsinstitusjonen}

Biesta $(2010,2013)$ peker på at en instrumentell rasjonalitet preger dagens skoleforståelse. Denne tendensen er også gjenkjennelig i norsk skole (Kristiansen, 2015) og inngår $\mathrm{i}$ en global testkultur der elevenes målbare læringsutbytte er sentralt (Ydesen \& Andreasen, 2020). VFL framheves som en bærer av dette ved å potensielt fordre en pedagogisk praksis som «krever et kontinuerlig fokus på mål og resultat» (Birkeland, 2018, s. 30). Biesta (2013) hevder videre at man i dag har flyttet oppmerksomheten fra utdanning og over til læring. Han kaller dette laringens politikkder politiske og samfunnsmessige utfordringer giøres til individuelle problemer som folk må læres opp til å håndtere (Biesta, 2013).

\section{Skolestress}

Stress kan forstås som et samspill mellom individet og omgivelsene (Lazarus \& Folkman, 1984). I skolen anser man en viss mengde stress hos individet som positivt for motivasjon og prestasjon, mens for mye stress virker negativt (Bru, 2019). I denne studien forstår vi skolestress som sosialt organisert (Smith, 2005), og vi undersøker hvordan jentenes erfaringer og gjøremål kan være knyttet til føringer i skolesystemet. Skolestress kan dermed betraktes som delte erfaringer mellom flere elever i skolehverdagen, selv om det vil variere i hvilken grad de selv er stresset.

\section{Metode}

\section{Intervjuprosess og datamateriale}

Vi har intervjuet ti jenter på tiende trinn i skoleåret 2017/2018 fra tre skoler i Agder. Vi informerte $i$ klassene om at vi ønsket å finne ut mer om jenters hverdag fordi en del jenter sier de er stresset, nedfor eller slitne. Det ble spesifisert at det var mulig å delta selv om man ikke hadde egenopplevde erfaringer med dette, og på denne måten

\footnotetext{
${ }^{1}$ Originalt sitat på engelsk: «people--always and only people» (DeVault, 2020, s. 84).
} 


\section{F. Lund, O. F. Madsen \& S. H. Haugland}

ble det åpnet for et bredt tilfang av deltakere. Jentene meldte seg på via SMS eller e-post til intervjuer. Prosjektet er godkjent av NSD (prosjektnummer 54 284). Deltakelse, og hva jentene ville si noe om, var frivillig. Dette ble det minnet om underveis $i$ intervjuene. I intervjufasen hadde intervjueren psykologfaglig rådgiver tilgjengelig for anonym drøfting om etiske problemstillinger og ivaretakelse av potensielt sårbare informanter (France, 2004).

Intervjumetoden er inspirert av etnografisk intervju (Spradley, 2016) og livsformsintervju (Haavind, 2019) (se tabell 1 for intervjuoversikt). Alle jentene ble intervjuet to ganger for å oppnå en bred beskrivelse av hverdagen og følge opp og utdype utsagn og tematikk. Intervjuene var refleksive (Alvesson \& Sköldberg, 2000), og intervjuer fulgte opp temaer på tvers av informanter. Ved hjelp av en visuell framstilling, et hverdagsskjema som intervjuer lagde mellom de to intervjuene, plasserte jentene stresset $\mathrm{i}$ sin egen hverdag. To av jentene deltok i et tredje intervju. De to ble valgt fordi de viste interesse av å drøfte jevnaldrendes hverdag. Intervjuer brakte inn aktuelle temaer basert på de første 20 intervjuene og relevant teori om samtidskultur. ${ }^{2}$ Det foregikk en tydeligere fortolkningsprosess før disse intervjuene som tilføyde ytterligere refleksivitet i intervjuprosessen (Alvesson \& Sköldberg, 2000). For å øke gjennomsiktighet i analysen spesifiserer vi når det henvises til disse intervjuene. Lydopptakene (ca. 17 timer) er transkribert og anonymisert. I tillegg har vi samlet inn tekster som er nevnt i intervjumaterialet (ukeplaner, prøver, målark og vitnemål), fra skoler i Agder.

Tabell 1. Intervjuoversikt

\begin{tabular}{lll}
\hline & Informanter & Innhold \\
\hline Intervju 1 & Ti individuelle & - Fortelle om en hverdag fra morgen til kveld \\
& intervjuer med & - Få oppfølgingsspørsmål og utdypende spørsmål \\
& ti jenter & \\
\hline Intervju 2 & Ti individuelle & - Intervjuer presenterer hverdagsskjemaet, drøfter om noe mangler \\
& intervjuer med & - Intervjuer stiller oppfølgingsspørsmål relatert til stress \\
& de samme ti & - Informantene forklarer ordet «stress» eller «stressa» uten å si selve ordet \\
& jentene & - Informantene skraverer stress i hverdagsskjemaet. Materialet inneholder \\
& & åtte slike skjemaer. \\
\hline Intervju 3 & To individuelle & - Refleksive intervjuer, intervjuer drøfter temaer med hver av informantene. \\
& intervjuer med & Temaene er måling; forbedre seg og å gjøre sitt beste; åpenhet om psykisk \\
& to av jentene & helse. \\
\hline
\end{tabular}

\section{Analytisk framgangsmåte}

Vi har primært forholdt oss til beskrivelsene av det jentene selv sier om eget og jevnaldrendes stress, og det de har skravert i hverdagsskjemaet. Vi har også latt beskrivelser av at de ikke føler seg stresset (av noe) være med fordi det står i kontrast til

2 Den terapeutiske kultur (Madsen, 2017); Forbedringsindustrien (Næss, 2016); Beyond learning (Biesta, 2006). 
skolestresset. På denne måten har vi nærmet oss skolestress ved hjelp av flere ulike vinklinger.

Den bærende ideen i analysen er å se jentenes erfaringer med skolestress opp mot institusjonelle føringer. Vi har lest intervjumaterialet og trukket ut hva slags arbeid jentene gjør relatert til faglig skolestress. I tråd med Smiths (2005) brede definisjon av arbeid handler dette om å gjennomføre en prøve, men også bekymringer i forkant, forberedelsestid og koordinering for å få tid blant hverdagens andre gjøremål. $\mathrm{Vi}$ indekserte materialet ved å betegne det med ulike former for arbeid, men uten mål om å sortere alt inn under faste temaer (Rankin, 2017). Vi gikk fram og tilbake mellom hver enkelt jentes arbeid og sammenstilte arbeidstyper for alle jentene. Vi så at vurdering og karakterer var et sentralt punkt som mye av arbeidet knyttet til skolestress sirklet rundt, og kalte det derfor vurderingsarbeid. Vi undersøkte også hvilke tekster av lavere orden som ble nevnt i vurderingsarbeidet, og hvilke bruddlinjer (Breimo, 2015) som var synlige. Begrepet bruddlinje stammer fra det engelske disjuncture og er et punkt i datamaterialet der det jentene snakker om, «ikke går opp", og der det er en avstand mellom det jentene faktisk gjør og det som forventes av dem (DeVault, 2020). Deretter undersøkte vi hvilke høyere ordens tekster bruddlinjene kunne peke mot.

\section{Resultat}

\section{Vurderingsarbeid og tekster i institusjonelt kretsløp}

Vurderingsarbeidet relatert til skolestress innbefatter alt jentene gjør med prøver, innleveringer, presentasjoner, tentamener og eksamener. Vi vil nå vise hvordan jentenes vurderingsarbeid inngår $i$ et institusjonelt kretsløp bestående av forberedelser, testing, vurdering, ny forberedelse og ny testing. Dette kretsløpet drives av tekster som ukeplan, prøve, målark og karakter - som alle er direkte til stede i hverdagen.

Stresset er mest utpreget i selve giennomføringen av prøver og framføringer, hvor det får tydelige uttrykk; som å løpe gråtende fra skolen. Likevel er det ikke i selve testgjennomføringen hovedvekten av vår analyse befinner seg, men i for- og etterarbeidet til disse testsituasjonene. Det er her det meste av vurderingsarbeidet foregår. Vi presenterer tre områder av jentenes vurderingsarbeid som utpeker seg gjennom bruddlinjer. Deretter presenterer vi hvordan tekster av lavere ordens rang framtrer $\mathrm{i}$ funnene.

\section{Arbeid for å definere innsats}

Forberedelsesfasen handler om å forberede seg, øve og giøre nok innsats, slik at resultatet blir bra. Det virker imidlertid uklart for jentene hvor mye de egentlig bør forberede seg. Dermed handler vurderingsarbeidet om et mentalt arbeid for å forsøke å definere hva som er nødvendig arbeid. Live har eksempelvis vært i dialog med læreren om hvor mye tid hun bruker på skolearbeid: 


\section{F. Lund, O. F. Madsen \& S. H. Haugland}

$[\mathrm{H}]$ un kontaktlæreren vår ... hun har sagt at jeg s... på en måte ... ee ... jeg må ikke bare prioritere skole, men jeg føler selv ikke at jeg gjør det, men at ... hun tror at jeg på en måte bruker mer tid på skole enn det jeg trenger ...

I Lives tilfelle forsøker læreren altså å moderere innsatsen hennes. Gina beskriver derimot en læringssituasjon der en strømlinjeformet forberedelse fra lærerens side giør at Ginas egen innsats virker ekstra prekær - fordi alt er tilrettelagt for at hun skal kunne gjøre det bra:

Naturfag er jo forholdsvis lett å gjøre det bra i [...]. Fordi liksom læreren er, hun er veldig flink, så det er, og hun gjør 1..., eller hun gjør slik at vi kan skrive gode notater og øve oss veldig, og vi blir veldig godt forberedt til prøver.» Intervjuer: «Mm.» Gina: «Så det er liksom, da blir jeg litt sånn skuffa hvis jeg får en dårlig karakter [...], fordi jeg vet at der har jeg faktisk så godt grunnlag at jeg kunne bare pugga litt ... hadde jeg pugga en halvtime til ...

I kontrast til denne tydelige læringsformen beskrives tentamen som ikke-stressende fordi de ikke kan forberede seg. Både Gina og Eva er jenter som i intervjuene beskriver at de stresser med karakterer, men Gina omtaler tentamen som chill, og Eva sier: «Tentamen og sånn er helt greit fordi det er liksom ikke noe man kan forberede seg så veldig til, eller hvis du skjønner, det er liksom ... siden man vet ikke helt hva slags oppgave man får.» På den måten signaliserer et opplegg med mindre detaljerte instrukser i forkant at det ikke forventes å legge ned så mye innsats i å øve og pugge.

Nora oppgir ikke at hun stresser med skoleresultater, og hun synes mange andre overdriver skolearbeidet. Likevel ser vi at hun i vurderingsarbeidet sitt reiser tvil om hun legger ned en tilstrekkelig egeninnsats: «Det er ... det er ikke sånn ekstremt mye heller. Men så gjør jo ikke jeg lekser. Som jeg kanskje burde gjort.»

\section{Forberedelser og arbeid for å koordinere tid}

Forberedelsesfasen handler videre om å fordele tiden sin mellom ulike oppgaver. Når det er flere prøver eller innleveringer i samme periode, er det stressende å prioritere tidsbruk i ukedagene og helgene og mellom skolearbeidet og fritidsaktiviteter. Jentene erfarer noen ganger at det ikke er nok tid til å gjøre alt. Vurderingsarbeidet handler her om å velge hva de skal bruke mest tid på, og hva som er viktig. Eva beskriver at prøvene ikke er jevnt fordelt, og at det er stressende når det er flere prøver på en uke. Susanne beskriver at hun er stresset hver dag: «[N] oen ganger så er det mye å gjøre, og jeg må øve til en prøve. Jeg føler at jeg drukner litt i det.» Hun trente mange ganger i uka tidligere, men er på intervjutidspunktet skadet. Dette beskriver hun som positivt med tanke på skolen fordi hun da har mer tid til lekser.

Vurderingsarbeidet og tidskoordinering er ikke like prekært for alle jentene i vårt materiale. Noen av dem har lagt seg på en annen standard, men de registrerer tidspresset rundt seg og beskriver seg selv i kontrast til dette. Julie sier: «Jeg leser jo ikke fem tim... timer til dagen, jeg bare giør lekser, og så prøver jeg å ha det gøy og slappe 
av.» Nora forbereder seg ikke til prøvene. Hun sier hun har hørt at det er mye prøver, «men det er ... kanskje jeg bare ... jeg som ikke helt får med meg at det er så mange prøver, fordi at jeg sjekker ikke, jeg bare tar det hvis jeg får en prøve så ...». Ved å bare ta prøvene spontant unnslipper hun tidskoordineringen helt.

\section{Forbedringsarbeid}

Jentene tar stilling til de vurderingene de har fått på forrige prøve, for å forbedre seg, og forbedring nevnes direkte i forbindelse med belastninger med skolearbeidet. Ut fra det de beskriver, virker det som om de prøver å leve opp til en høy standard som stadig flytter seg. Lotte og Gina uttaler eksempelvis at de vil øke sitt eget snitt fra år til år. Gina sier: "Jeg blir skikkelig skuffet hvis ikke snittet mitt går opp hvert år.» Susanne snakker også mye om at hvis det ikke går bra på en prøve, må hun øve mer til neste og få bedre resultat på den. Charlotta sier hun ikke opplever skolestress, men påpeker likevel fenomenet med at det alltid kan bli bedre: «Det er liksom prøver, og det er lærere som maser, og det er liksom, det blir liksom ikke bra nok.» Nora motsetter seg ganske tydelig forbedring og giør ikke det beste hun kan, hun gir uttrykk for at hun ikke ser verdien av å få så gode karakterer: «Jeg vet at det hadde gått mye bedre på skolen hvis jeg hadde gjort lekser, men [...] jeg gidder ikke rett og slett, jeg er for lat.» Ifølge Nora er hun til stede på skolen, deltar muntlig i timene og giennomfører prøvene. Til tross for dette ser det ut til at hun opplever å falle utenfor en slags standard ved å ikke forsøke å forbedre seg og gjøre det beste hun kan. I intervjuet med Nora snakker vi om at det ikke virker som om det plager henne særlig at hun ikke giør det hun burde på skolen. Hun sier: «Nei. Tenker at ... ee ... Det er jo sikkert litt dumt, da - at jeg ikke føler eller lærer så mye som jeg burde eller sånn, eller det som er liksom planen, da.»

\section{Tekster av lavere ordens rang i datamaterialet}

Vi konsentrerer oss om tekstene målark og karakter fordi det er her bruddlinjene er tydelige. Ukeplanen er med fordi den formidler en konkret forbindelse både til karakterer via prøver og tester og målark.

\section{Ukeplan og målark som tekst $i$ datamaterialet}

Ukeplanen er fysisk til stede i jentenes hverdag. Den viser hva som er av betydning i kommende uke, hva som skal vurderes og når. Nora henviser til ukeplanen da vi spør henne hva det er hun burde giøre, og Susanne beskriver at hun blir stresset når hun ser på ukeplanen at det skal være en stor prøve. Mye av vurderingsarbeidet som jentene beskriver, og tekstene de nevner, er inkorporert i ukeplanen, hvor det står formuleringer som "test», «skrivedag》, 《framføring», «forberedelse til tentamen", «forbered deg til test $[\ldots]$, se kjennetegn på måloppnåelse og tren på de målene du trenger». Mål og kjennetegn på måloppnåelse viser til innholdet i et målark. Målarket nevnes i forbindelse med prøver. Susanne snakker om at lærerne forbereder prøver på skolen ved hjelp av målark der det står konkret hva elevene kan få på prøven. Charlotta, som 


\section{F. Lund, O. F. Madsen \& S. H. Haugland}

ikke stresser med skolearbeid, sier: «Jeg pleier egentlig ikke å følge så mye med i timen fordi, som sagt, alt handler jo om karakterer, så jeg ... jeg bare leser p..., jeg pleier bare lese på målarket, så pleier det å gå fint.» Målark er et skjematisk oppsett inndelt etter læringsmål og hva man må kunne for lav (karakter 2), middels (karakter 3-4) eller høy (karakter 5-6) måloppnåelse i henhold til relevant kompetansemål fra læreplanen.

\section{Vurdering med karakter som tekst $i$ datamaterialet}

Jentene får karakter i form av et tall som sier noe om prestasjonen deres. Karakteren publiseres for eksempel giennom den digitale plattformen itslearning.

Karakteren er stressende $i$ tiende klasse fordi den legger grunnlaget for standpunktkarakteren og kobles til inntak på videregående skole. Eva beskriver det som at det er nå det gjelder, og at "en prøve er ikke bare en prøve». Susanne snakker også om arbeidet med prøvene knyttet opp til endelig sluttresultat: «Dette er jo på en måte den karakteren som har noe å si for min fremtid på en måte, for den teller jo på vitnemålet.» Hun gir uttrykk for at det er mye prøver nå, men at «det må vi på en måte ha ... for det skal jo ... vi må jo få en vurdering ... i fagene».

Det er karakteren som til slutt definerer for jentene om de har øvd og gjennomført tilstrekkelig, noe som illustreres av Gina da hun sier: «Jeg var ikke fornøyd med hva jeg hadde gjort, jeg syntes ikke den var noe bra. Men det gikk jo veldig fint. Jeg ble, jeg var liksom overrasket: ... Vi får karakter ...» I jentenes forbedringsarbeid er det karakteren de vil forbedre. Det å forbedre snittkarakteren sin fra år til år er krevende fordi de faglige kravene øker på høyere trinn. I refleksjonsintervjuet med Lotte drøfter vi prestasjoner og det å gjøre sitt beste, og det kommer fram at til og med den beste karakteren kan bli bedre. Intervjuer spør om det noen gang er bra nok:

Lotte: «Jeg tror egentlig ikke det.»Intervjuer: «Nei». [...] Lotte: «Ee ... for det på en prøve, så er det sånn ... okei, jeg får en sekser, men det er jo sånn knapt, liksom. Hvis jeg først får en sekser, så er det knapt, og da tenker man jo sånn, man kan jo forbedre det enda litt mer sånn at det er en skikkelig sekser.»

Når jentene snakker om hvordan de skal forbedre en karakter, handler dette om å bruke mer tid på å forberede seg. Forbedringsarbeidet er dermed filtret sammen med arbeidet for å koordinere tid og å definere innsats fordi en forbedret karakter er jentenes mål på om de brukte nok tid og la ned god nok innsats.

\section{Drøfting}

I det følgende belyser vi hvordan jentenes vurderingsarbeid, tekstene av lavere orden og det institusjonelle kretsløpet samspiller med høyere ordens tekster. ${ }^{3}$ Figur 1 viser en oversikt over de ulike tekstene.

\footnotetext{
${ }^{3}$ Vi har forholdt oss til tekster som var gjeldende da vår studie ble gjennomført. Samtidig viser vi til nyere tekster og påpeker der det er vesentlige endringer, eksempelvis forskrift til opplaringslova av 2009 og 2020.
} 


\section{Bruddlinjer mellom jentenes vurderingsarbeid og tekstenes hensikt}

Karakteren skal kun representere den oppnådde kompetansen i faget, innsats teller ikke på karakteren (Forskrift til opplæringslova, 2009b, 2020d; Utdanningsdirektoratet, 2018a). Likevel, når jentene forbereder seg og gjennomfører prøven eller framføringen, settes det en karakter som implisitt definerer for dem om innsatsen var god nok. Når jentene erfarer det slik, bryter det med karakterens egentlige hensikt.

Gjeldende læreplan for jentene i denne studien er Kunnskapsløftet LK06 (Utdanningsdirektoratet, 2006). Målark er en praksis som kommer fra satsingen Vurdering for laring (VFL) med søkelys på læring, utvikling og prosess gjennom underveisvurdering (Slemmen, 2010; Utdanningsdirektoratet, 2019). Det ser imidlertid ikke ut til at jentene knytter det til prosess, men til sluttresultatet. Dette er et brudd mellom tekstenes hensikt og hvordan det arter seg i jentenes liv.

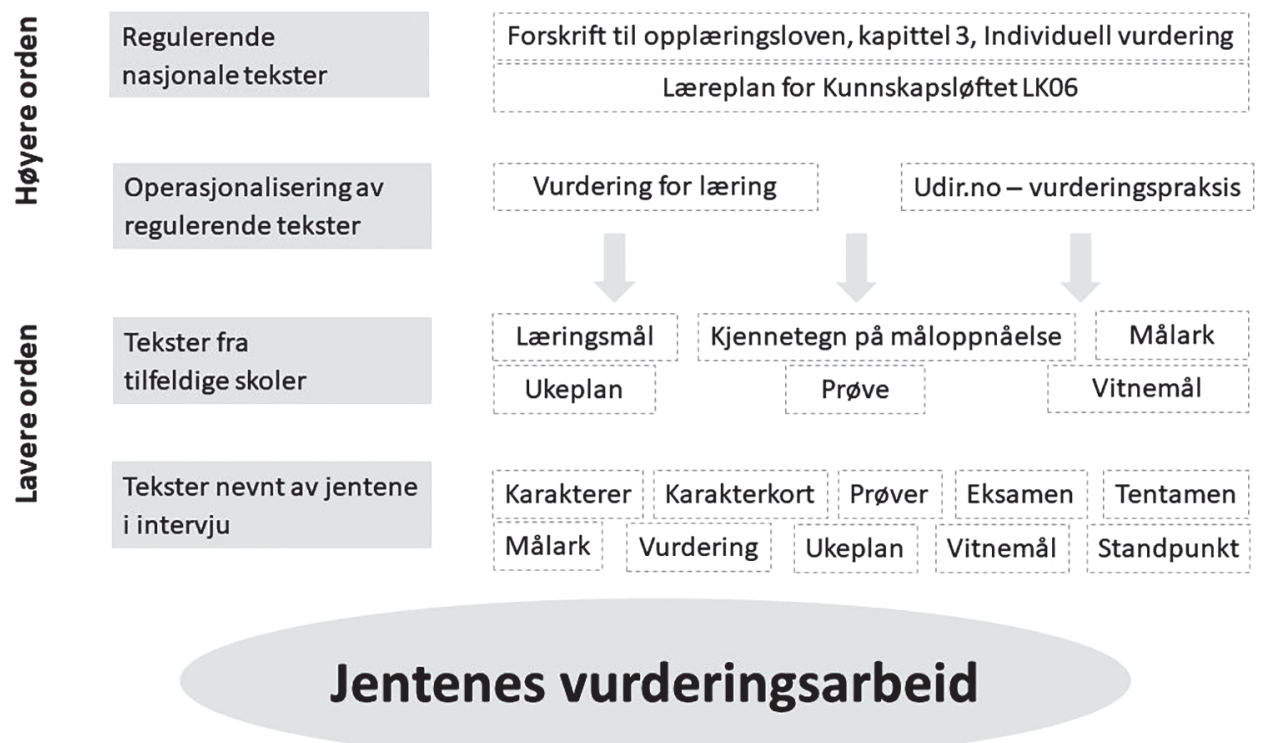

Figur 1. Kart over høyere og lavere ordens tekster.

\section{Vurderingsarbeid og styring gjennom høyere ordens tekster}

Hvordan jentene kan forbedre karakteren, framgår av målarket der det står hva de må kunne for å heve seg. VFL baserer seg på at elevene lærer bedre når de

1) forstår hva de skal lære, og hva som forventes av dem

2) får tilbakemeldinger som forteller dem om kvaliteten på arbeidet eller prestasjonen

3) får råd om hvordan de kan forbedre seg

4) er involvert i eget læringsarbeid ved blant annet å vurdere eget arbeid og utvikling (Utdanningsdirektoratet, 2015, 2019) ${ }^{4}$

${ }^{4}$ Utdanningsdirektoratets nettressurs fra 2015 er nå endret, men prinsippene er gjengitt i sin helhet i erfaringsrapporten fra 2019. 
På Utdanningsdirektoratets nettsider har det blitt presisert at bruk av kompetansemål, kjennetegn og kriterier er avgjørende for at elevene skal ha oversikt over egen læring og progresjon (Utdanningsdirektoratet, 2016b). ${ }^{5}$ Dette er begreper vi kjenner igjen fra de lokale målarkene som er i bruk i skolen. I tillegg hevdes det at det er motiverende for elever «når de får mulighet til å bruke tilbakemeldinger til å forbedre arbeidet eller prestasjonen sin" (Utdanningsdirektoratet, 2016a, avsnitt 9; 2020, avsnitt 10). Hva som er god nok innsats for å oppnå forbedringen, er imidlertid ikke uttalt i satsingen og noe jentene strever med å finne ut av.

I forskrift til oppleringsloven er det lovfestet at elevene skal motta vitnemål med standpunktkarakterer som skal baseres på et bredt vurderingsgrunnlag, vise samlet kompetanse i faget, og vurderingsgrunnlaget skal være kjent for eleven (Forskrift til opplæringslova, 2009c, 2009d, 2020b, 2020c). ${ }^{6}$ Når grunnlaget skal være tydelig for elevene, betyr det også at man må ta hensyn til vurderingskriterier og karakterer slik jentene i vårt datamateriale beskriver. Kobling av målark til prøver og vurdering som jentene opplever i hverdagen, passer også med dette lovpålagte kravet om bredt og informert vurderingsgrunnlag, men det bryter med ideen om underveisvurdering som noe annet enn sluttvurdering (Slemmen, 2010). Underveisvurdering og forbedring er ment å handle om prosessen, men for jentene blander dette seg med sluttvurdering fordi underveisvurderingene teller med i standpunktkarakterene som kommer på vitnemålet. Forviklingen er også tydelig både i forskriften, der det står at underveisvurdering og sluttvurdering skal sees i sammenheng (Forskrift til opplæringslova, 2009a), og i Utdanningsdirektoratets formulering: «Sammenhengen mellom underveisvurderingen og standpunktkarakteren i fag [...]. Den kompetansen eleven viser i løpet av opplæringen, er en del av grunnlaget for vurderingen når standpunktkarakteren i fag skal fastsettes» (Utdanningsdirektoratet, $2018 \mathrm{~b}$, del II $\ 3-16$ ). ${ }^{7}$ På mange måter blir dette en kontinuerlig sluttvurdering med forbedringspotensial og for noen bidrar dette til skolestress.

Gjennomsnittet av alle standpunktkarakterer samt eksamenskarakterer på vitnemålet er tellende når elevene skal søke på videregående skole. Jentene i vårt materiale som gir uttrykk for å stresse med dette, sier imidlertid at de vet at de har høyt nok snitt for å komme inn der de vil. Det ser altså ikke ut som om det er inntakskravet $\mathrm{i}$ seg selv som er avgjørende.

I 2010 ble VFL innført for å heve standarden i skolen og å jobbe fram en bedre vurderingskultur. Satsingen er en operasjonalisering av regulerende nasjonale tekster og internasjonale anbefalinger og inngår i Kunnskapsløftet (Utdanningsdirektoratet,

\footnotetext{
${ }^{5}$ Nettsiden er endret og finnes ikke lenger.

${ }^{6}$ I endret forskrift av 2020 er formuleringen med «baseres på et bredt vurderingsgrunnlag» fjernet.

${ }^{7}$ I ny forskrift av 2020 er dette endret til å gjelde halvårsvurdering. Halvårsvurdering skal gis både som muntlig eller skriftlig underveisvurdering og suppleres med karakter, se forskrift til opplæringslova, 2020a.
} 
2019). OECD anbefalte at Norge skulle jobbe for at underyterne i elevmassen skulle yte og prestere bedre, og det ble anbefalt å innføre tydeligere mål og økt kontroll på læringen (Mortimore et al., 2005; Utdanningsdirektoratet, 2019). I Utdanningsdirektoratets evalueringsrapport av VFL i skolen trekkes «økt fokus på tydelige læringsmål og forventninger, hyppigere bruk av mål og kjennetegn, bedre tilbakemeldingspraksis med tydelige og konkrete tilbakemeldinger» fram som positive endringer i vurderingspraksis (Utdanningsdirektoratet, 2019, s. 19). I den nye læreplanen fra 2020 presenteres også den tydelige lærings- og vurderingskulturen som utelukkende positiv for elevene: «Når elevene forstår sine egne læringsprosesser og sin faglige utvikling, bidrar det til selvstendighet og mestringsfølelse» (Kunnskapsdepartementet, 2017, s. 12). Dette står i kontrast til det vurderingsarbeidet jentene $i$ vårt datamateriale giør, hvor forståelsen av den faglige utviklingen i stor grad handler om karakterer som skaper stress framfor mestring. Det gir grunn til å stille spørsmål ved om disse endringene i praksis er positive for alle elever.

\section{Unge jenters relasjoner til styringer i utdanningsinstitusjonen}

Samspillet som foregår mellom utdanningsinstitusjonens føringer og jentenes vurderingsarbeid, synliggiør dreiningen mot målbar og styrt læring som Biesta (2013) er kritisk til. I den strukturerte læringsformen kan det også virke som om læringen er så «sikker» at den eneste usikre faktoren er jentenes egen innsats.

Jentene relaterer seg til styringene på ulikt vis. Når Nora motsetter seg å lære «det som er liksom planen", står hun i opposisjon til hva som ønskes av elevene, og motsetter seg dermed læringsplikten (Biesta, 2013). Charlotta bruker prinsippene om tydelig og målbar læring til sin fordel ved bare å lese målarket før prøvene. Hun tar samtidig avstand fra at man er så konsentrert om resultater i skolen: «Nå, så handler jo alt bare om å prestere, men ikke å fullføre. $\mathrm{Da}$, altså før, så handlet det jo bare om å få mest mulig folk til å være ... funke i samfunnet. Og det er jo det vi burde sette fokus på.» Nora og Charlotta nedvurderer dermed styringen og det at det er målrettet læring som gjelder. Dette blir problematisk fordi de da defineres, eller definerer seg selv, utenfor det som verdsettes i skolen. Andre etterlever etterspørselen om en stadig målbar forbedring gjennom strukturert egeninnsats. Lotte hevder at en sekser kan forbedres, og Susanne og Gina legger vekt på sin egen tidsbruk og innsats for å forbedre de allerede høye karakterene. Den strukturerte læringen, den tydelige individuelle vurderingen og oppmerksomheten som er viet forbedring, er problematisk fordi denne instrumentelle læringsformen inviterer til å sette prestasjonen i fokus og til en type arbeid som kan være belastende for unge mennesker ved at det aldri er bra nok. Dermed kan en god pedagogisk intensjon få uheldige utfall.

I vår studie ser vi at det institusjonelle kretsløpet med målark, prøveforberedelser, prøver, karakterer og vitnemål kan bidra til skolestress og manglende mestring, selv om dette ikke er intensjonen bak styringen. De som i stor grad lever opp til forventningene fra utdanningssystemet, kan i neste omgang være elever som man bekymrer 


\section{F. Lund, O. F. Madsen \& S. H. Haugland}

seg for fordi de er stresset, og ofte møtes disse som om utfordringene ligger på et individuelt nivå, mens de snarere bare responderer på styringene i et system.

\section{Kritisk refleksjon om studiens gyldighet}

Utvalget i denne studien består av jenter som aktivt har meldt seg for å snakke om egen eller andres erfaring med stress eller slitenhet. Denne rekrutteringsmetoden kan ha gitt en skjevhet i utvalget, og sammen med utvalgets størrelse begrenser det muligheten for å generalisere funnene til å gjelde jenter generelt. Utvalget kan imidlertid sies å være hensiktsmessig og informasjonsrikt (Patton, 2002), idet det tjener til å belyse relasjonen mellom målstyring og skolestress (vurderingsarbeid) og hvordan styringen framtrer gjennom tekster av lavere og høyere orden (Smith, 2002).

\section{Avsluttende kommentar}

Denne studien peker på at skolestress kan forstås som et strukturelt problem og som et fullt forståelig tilsvar til styringsrasjonaliteten i skolen. I en tid der individets ansvar og mestring vektlegges, bør man i møte med økende skolestress i større grad kritisk granske hvordan de strukturelle styringene i utdanningsinstitusionen kan bidra til denne utviklingen, framfor å ensidig være opptatt av individuell mestring blant elevene.

\section{Om artikkelen}

Artikkelen inngår som en del av et doktorgradsprosjekt ved Universitetet i Agder (UiA). En spesiell takk rettes til forskningsgruppa Institusjonell etnografi ved UiA for drøftinger rundt metode og analyse samt gjennomlesing av manus.

\section{Forfatteromtale}

Janne Lund er doktorgradsstipendiat ved Institutt for psykososial helse, Universitetet i Agder. Forskningsinteressene hennes inkluderer barn, ungdom, normalitet og samfunn. Hun er opptatt av å forstå barn og unges livsverden i relasjon til samtiden.

Ole Jacob Madsen er professor ved Psykologisk institutt, Universitetet i Oslo. Han forsker på psykologiens rolle i samfunnet. Spesielt har han jobbet med samtidsdiagnosen «den terapeutiske kultur». Han er forfatter av bla. Generasjon prestasjon og Livsmestring på timeplanen - rett medisin for elevene?

Siri Håvås Haugland er førsteamanuensis og instituttleder ved Institutt for psykososial helse, Universitetet i Agder. Forskningen hennes omfatter ungdom, epidemiologi, folkehelse, levekår og foreldre- og oppvekstsvilkårenes betydning for psykososial helse. 


\section{Å giøre «det som er liksom planen, da»}

\section{Referanser}

Alvesson, M. \& Sköldberg, K. (2000). Reflexive methodology. Sage.

Anniko, M. K., Boersma, K. \& Tillfors, M. (2019). Sources of stress and worry in the development of stressrelated mental health problems: A longitudinal investigation from early- to mid-adolescence. Anxiety, Stress, E Coping, 32(2), 155-167. https://doi.org/10.1080/10615806.2018.1549657

Biesta, G. J. J. (2006). Beyond learning. Routledge.

Biesta, G. J. J. (2010). Good education in an age of measurement. Routledge.

Biesta, G. J. J. (2013). The beautiful risk of education. Routledge.

Birkeland, N. R. (2018). Vurdering for læring - en trojansk hest i skolen? Tidsskriftet Sakprosa, 10(2), 1-35. https://doi.org/10.5617/sakprosa.6023

Breimo, J. P. (2015). Rehabilitering. Samordningsproblematikk sett fra et ståsted. I L. Widerberg (Red.), I hjertet av velferdsstaten. En invitasjon til institusjonell etnografi (s. 79-100). Cappelen Damm Akademisk.

Bru, E. (2019). Stress og mestring i skolen - en forståelsesmodell. I E. Bru \& P. Roland (Red.), Stress og mestring i skolen (s. 19-46). Fagbokforlaget.

Campbell, M. \& Gregor, F. (2004). Mapping social relations. A primer in doing institutional ethnography. Alta Mira Press.

DeVault, M. L. (2020). Institutional ethnography: A mode of inquiry and a strategy for change. I A. Marvasti \& A. J. Trevino (Red.), Researching Social Problems (s. 83-101). Routledge.

Eriksen, I. M., Sletten, M. A., Bakken, A. \& von Soest, T. (2017). Stress og press blant ungdom. Erfaringer, årsaker og utbredelse av psykiske helseplager (NOVA Rapport 6/17). https://hdl.handle.net/20.500.12199/5115

Forskrift til opplæringslova. (2009a). Forskrift om endring $i$ forskrift til oppleringslova, FOR-2009-07-01-964, Formålet med vurdering [\$3-2]. https://lovdata.no/pro/\#document/LTI/forskrift/2009-07-01-964

Forskrift til opplæringslova. (2009b). Forskrift om endring i forskrift til oppleringslova, FOR-2009-07-01-964, Grunnlaget for vurdering i fag [\$3-3]. https://lovdata.no/pro/\#document/LTI/forskrift/2009-07-01-964

Forskrift til opplæringslova. (2009c). Forskrift om endring i forskrift til oppleringslova, FOR-2009-07-01-964, Standpunktkarakterer i fag [\$3-18]. https://lovdata.no/pro/\#document/LTI/forskrift/2009-07-01-964

Forskrift til opplæringslova. (2009d). Forskrift om endring $i$ forskrift til oppleringslova, FOR-2009-07-01-964, Vitnemål i grunnskolen [\$3-40]. https://lovdata.no/pro/\#document/LTI/forskrift/2009-07-01-964

Forskrift til opplæringslova. (2020a). Forskrift om endring $i$ forskrift til oppleringslova og forskrift til friskolelova, FOR-2020-06-29-1474, Halvårsvurdering $i$ fag [\$ 3-12]. https://ovdata.no/pro/\#document/LTI/ forskrift/2020-06-29-1474

Forskrift til opplæringslova. (2020b). Forskrift om endring i forskrift til oppleringslova og forskrift til friskolelova, FOR-2020-06-29-1474, Standpunktkarakterar $i$ fag [\$3 3-15]. https://lovdata.no/pro/\#document/LTI/ forskrift/2020-06-29-1474

Forskrift til opplæringslova. (2020c). Forskrift om endring $i$ forskrift til opplaringslova og forskrift til friskolelova, FOR-2020-06-29-1474,Vitnemål i grunnskolen [\$3-37]. https://lovdata.no/LTI/forskrift/2020-06-29-1474

Forskrift til opplæringslova. (2020d). Forskrift om endring i forskrift til opplaringslova og forskrift til friskolelova, FOR-2020-06-29-1474, Vurdering i fag [\$ 3-3]. https:/lovdata.no/LTI/forskrift/2020-06-29-1474

France, A. (2004). Young people. I S. Fraser, V. Lewis, S. Ding, M. Kellett \& C. Robinson (Red.), Doing research with children and young people (s. 175-190). Sage.

Griffith, A. \& Smith, D. E. (2014). Under new public management: Institutional ethnographies of changing front-line work. University of Toronto Press.

Hopfenbeck, T. N., Petour, M. T. F. \& Tolo, A. (2015). Balancing tension in educational policy reforms: Largescale implementation of Assessment for Learning in Norway. Assessment in Education: Principles, Policy \& Practice, 22(1), 44-60. https://doi.org/10.1080/0969594X.2014.996524

Högberg, B., Strandh, M. \& Hagquist, C. (2020). Gender and secular trends in adolescent mental health over 24 years - the role of school-related stress. Social Science \& Medicine, 250. https://doi.org/10.1016/ j.socscimed.2020.112890

Haavind, H. (2019). Livsformsintervjuet: En veiviser til subjektive erfaringer. I A. Jansen \& A. Andenæs (Red.), Hverdagsliv, barndom og oppvekst. Teoretiske posisjoner og metodiske grep (s. 26-56). Universitetsforlaget.

Kristiansen, A. (2015). Educational challenges in the shadow of instrumentalism. I S. Hillen \& C. Aprea (Red.), Instrumentalism in education -Where is Bildung left? (s. 117-130). Waxmann.

Kunnskapsdepartementet. (2017). Verdier og prinsipper for grunnoppleringen - overordnet del av lereplanverket. Regjeringen. https://www.regjeringen.no/no/dokumenter/verdier-og-prinsipper-for-grunnopplaringen/id2570003/ 


\section{F. Lund, O. F. Madsen \& S. H. Haugland}

Lazarus, R. S. \& Folkman, S. (1984). Stress, appraisal, and coping. Springer.

Lillejord, S., Børte, K., Ruud, E. \& Morgan, K. (2017). Stress i skolen - en systematisk kunnskapsoversikt. Kunnskapssenter for utdanning. https://utdanningsforskning.no/globalassets/stress-i-skolen---en-systematiskkunnskapsoversikt.pdf

Madsen, O.J. (2017). Den terapeutiske kultur (2. utg.). Universitetsforlaget.

Moksnes, U., Løhre, A., Lillefjell, M., Byrne, D. \& Haugan, G. (2016). The association between school stress, life satisfaction and depressive symptoms in adolescents: Life satisfaction as a potential mediator. Social Indicators Research, 125(1), 339-357. https://doi.org/10.1007/s11205-014-0842-0

Mortimore, P., Field, S. \& Pont, B. (2005). Equity in education, thematic review: Norway countrynote OECD. OECD. https://www.oecd.org/education/innovation-education/35892523.pdf

Nilsen, A. C. (2015). Barneomsorg. På jakt etter styringsrelasjoner ved "tidlig innsats» i barnehagen. I K. Widerberg (Red.), I hjertet av velferdsstaten: En invitasjon til institusjonell etnografi (s. 32-51). Cappelen Damm Akademisk.

Nortvedt, G. A., Santos, L. \& Pinot, J. (2016). Assessment for learning in Norway and Portugal: The case of primary school mathematics teaching. Assessment in Education: Principles, Policy E Practice, 23(3), 377-395. https://doi.org/10.1080/0969594X.2015.1108900

Næss, H. E. (2016). Forbedringsindustrien. Et oppgjør med prestasjonskulturen. Cappelen Damm.

Opplæringslova. (2008). Lov om grunnskolen og den vidaregåande opplceringa (opplaringslova) [〔 1-1] (LOV-199807-17-61). Lovdata. https://ovdata.no/lov/1998-07-17-61

Patton, M. Q. (2002). Qualitative research E evaluation methods. Sage.

Rankin, J. (2017). Conducting analysis in institutional ethnography: Guidance and cautions. International Fournal of Qualitative Methods, 16(1). https://doi.org/10.1177/1609406917734472

Skaalvik, E. M. \& Federici, A. (2015). Prestasjonspresset i skolen. Bedre skole, (3), 11-15.

Slemmen, T. (2010). Vurdering for lcering $i$ klasserommet. Gyldendal Akademisk.

Smith, D. E. (1996). Telling the truth after postmodernism. Symbolic Interaction, 19(3), 171-202. https://doi. org/10.1525/si.1996.19.3.171

Smith, D. E. (2002). Institutional etnography. IT. May (Red.), Qualitative research in action (s. 17-52). Sage.

Smith, D. E. (2005). Institutional ethnography: A sociology for people. AltaMira.

Smith, D. E. (2006). Incorporating texts into ethnographic practice. I D. E. Smith (Red.), Institutional Ethnography as practice (s. 65-88). Rowman \& Littlefield.

Spradley, J. P. (2016). The ethnographic interview. Waveland Press.

Utdanningsdirektoratet. (2006). Kunnskapsløftet LK06. https://www.regjeringen.no/globalassets/upload/kilde/ ufd/prm/2005/0081/ddd/pdfv/256458-kunnskap_bokmaal_low.pdf

Utdanningsdirektoratet. (2015). Fire prinsipper for god underveisvurdering. Utdanningsdirektoratet. Hentet 28.04.20 fra https://www.udir.no/laring-og-trivsel/vurdering/om-vurdering/underveisvurdering/

Utdanningsdirektoratet. (2016a). Gode faglige tilbakemeldinger - Når skal du gi tilbakemeldinger? Hentet 18.05.2020 fra https:/www.udir.no/laring-og-trivsel/vurdering/underveisvurdering/tilbakemeldinger/

Utdanningsdirektoratet. (2016b). Fobb med lereplan, mål, kjennetegn og kriterier. Hentet 22.05.2020 fra https:// www.udir.no/laring-og-trivsel/vurdering/underveisvurdering/mal-og-kriterier/

Utdanningsdirektoratet. (2018a). Rundskriv, individuell vurdering, grunnlaget for vurdering $i$ fag [Del II $\left.\int 3-3\right]$. https:/www.udir.no/regelverkstolkninger/opplaring/Vurdering/individuell-vurdering-udir-5-2016/? depth=0\&print $=1 \# 3-3$

Utdanningsdirektoratet. (2018b). Rundskriv, individuell vurdering, sammenhengen mellom underveisvurderingen og standpunktkarakteren [Del II \3-16]. https://www.udir.no/regelverkstolkninger/opplaring/Vurdering/ individuell-vurdering-udir-5-2016/?depth=0\&print $=1$

Utdanningsdirektoratet. (2019). Erfaringer fra nasjonal satsing på vurdering for laring (2010-2018). https:// www.udir.no/tall-og-forskning/finn-forskning/rapporter/erfaringer-fra-nasjonal-satsing-pa-vurdering-forlaring-2010-2018/

Utdanningsdirektoratet. (2020). Gi gode faglige tilbakemeldinger - Når skal du gi tilbakemeldinger? Hentet 03.12.2020 fra https:/www.udir.no/laring-og-trivsel/vurdering/underveisvurdering/tilbakemeldinger/

West, P. \& Sweeting, H. (2003). Fifteen, female and stressed: Changing patterns of psychological distress over time. Fournal of Child Psychology and Psychiatry, 44(3), 399-411. https://doi.org/10.1111/1469-7610.00130

Ydesen, C. \& Andreasen, K. E. (2020). Historical roots of the global testing culture in Education. Nordic Studies in Education, 40(2), 149-166. https://doi.org/https://doi.org/10.23865/nse.v40.2229 